\title{
A Cross-Sectional Comparison of Drinking Patterns, Alcohol Use and Related Medical Morbidities in a Secondary Versus Tertiary Setting
}

\section{Risal A, ${ }^{1}$ Tharoor $\mathrm{H}^{2}$}

\author{
${ }^{1}$ Department of Psychiatry \\ Dhulikhel Hospital -Kathmandu University Hospital \\ Kathmandu University School of Medical Sciences \\ Dhulikhel, Kavre \\ Nepal \\ ${ }^{2}$ Schizophrenia Research Foundation \\ Chennai, India
}

\section{Corresponding Author}

Ajay Risal

Department of Psychiatry

Dhulikhel Hospital -Kathmandu University Hospital Kathmandu University School of Medical Sciences Dhulikhel, Kavre

Nepal

E-mail: drajayrisal@gmail.com

\section{Citation}

Risal A, Tharoor H. A Cross-Sectional Comparison of Drinking Patterns, Alcohol Use and Related Medical Morbidities in a Secondary Versus Tertiary Setting. Kathmandu Univ Med J 2013;42(2):152-157.

\section{ABSTRACT}

\section{Background}

Alcohol Dependence exists in different spectrums at different settings and associated with various medical morbidities, disability and health care utilization costs.

\section{Objectives}

To study the drinking patterns, alcohol use disorders and alcohol related medical morbidities in patients diagnosed with Alcohol Dependence Syndrome (ADS) and attending out / in-patient psychiatry services at secondary and tertiary care centre.

\section{Methods}

A cross-sectional comparative study was done among the patients diagnosed with ADS attending psychiatry services at District hospital, Udupi and Kasturba Hospital, Manipal. Serial sampling was done. Patients having any other psychiatric illnesses were excluded. The two groups were compared in relation to socio-demographic variables, drinking related variables, patterns of drinking and alcohol related medical morbidities identified.

\section{Results}

Significant differences in some socio-demographic parameters among the patients from the two different treatment centers were found with secondary level hospital $(\mathrm{N}=50)$ having more illiterate, laborers and below the poverty line population in comparison to the tertiary level hospital $(\mathrm{N}=75)$. Maximum frequency of gastrointestinal morbidities was seen in both the hospital population, irrespective of the patterns of drinking.

\section{Conclusion}

Alcohol use disorders and alcohol related medical morbidities show some variations in their presentations in the different treatment centers.

\section{KEY WORDS}

Alcohol dependence, medical morbidities, treatment center

\section{INTRODUCTION}

Alcohol is one of the most commonly used psychoactive drugs in the world. ${ }^{1}$ Distinction between moderate or social drinking and excessive or harmful drinking is often difficult but as the consumption of alcohol increases, incidence of psychosocial and medical problems also increases. ${ }^{2}$ Alcohol dependence syndrome (ADS) and, more generally, alcohol use disorders (AUDs) predispose individuals to adverse consequences that extend beyond the expected damage from alcohol related direct toxicity. ${ }^{1,2}$

In recent years, there has been a change in the trends of alcohol consumption, such as early age-of-onset of drinking, increasing usage among women, change in drinking patterns and increasing Alcohol Dependence problems even in the developing countries like India and Nepal. ${ }^{1}$ The South East Asian Region (SEAR) can be characterized as a Region with comparatively low (as 
compared to other Regions of the world), but increasing levels of drinking with a detrimental pattern, a key problem area being heavy episodic or "binge" drinking. ${ }^{2}$ Research has shown that the relationship of alcohol use to health outcomes is complex as is the etiology of ADS, and that the individual and social costs of alcohol related problems are increasing. Although new knowledge can assist in the development of appropriate medical management strategies, AUDs account for an important percentage of the global burden of disease requiring approaches that are not focused on the identification and treatment of alcohol dependence only. ${ }^{3}$ Alcoholic liver disease (ALD) is a major source of alcohol related morbidity and mortality. Heavy drinkers and alcohol dependents may progress from fatty liver to alcoholic hepatitis to cirrhosis, and it is estimated that $10-15 \%$ of this population will develop cirrhosis. Other associated medical morbidities include gastritis/peptic ulcer, nutritional deficiencies, pancreatitis, worsening of Diabetes mellitus, increased risk of strokes, arrhythmias, seizures and reduction of immunity and increased susceptibility to infections. ${ }^{4}$

Keeping a note as to different facets of the spectrum of Alcohol Dependence attending different care settings, we attempted this research aiming to study the drinking patterns, alcohol use disorders and alcohol related medical morbidities in patients diagnosed with ADS and attending out / in-patient psychiatry services at secondary care centre, Government District Hospital, Udupi and tertiary care centre, Kasturba Hospital, Manipal, India.

\section{METHODS}

This cross-sectional comparative study was initiated after clearance was obtained from the Institutional Ethics Committee (IEC) of Kasturba Hospital, Manipal, India. The study was conducted at two sites; Government district hospital, Udupi (group I) and Kasturba Hospital, a tertiary care hospital at Manipal (group II) in the state of Karnataka, India. It was done over the period of one year (April 2008 to April 2009). Patients taken up for the study were either in-patients in psychiatry wards of the above mentioned hospitals or those referred from other departments to psychiatry for the purpose of de-addiction treatment and evaluated by the consultant psychiatrist. Patients of age 18 and above diagnosed to have Alcohol Dependence Syndrome based on DSM-IV criteria and consenting for the study were taken up. ${ }^{5}$ Patients having any other substance dependence except nicotine dependence, those with comorbid Axis I diagnosis, having independent seizure disorder, Mental retardation and those with alcohol withdrawal related delirium were excluded. Patients were interviewed when they were medically stable. Written informed consent was taken from all the subjects after explaining the details mentioned in the subject information sheets which was designed in both Kannada and English and used as was needed. Consent forms were also designed in both Kannada and English. The assessments were separate from their regular management. No investigation or treatment was suggested or advised for the study. During the study period, total of 50 patients fulfilled the inclusion criteria in Udupi District Hospital, while 75 in Kasturba Hospital. All the patients consented for the study. The subjects were interviewed. Socio-demographic proforma and physical examination proforma were filled up. Investigations done were entered. Medical morbidity, if any, as per evaluation by the Physician /Consultant was entered. Severity of alcohol dependence was evaluated as per SAD-Q criteria. ${ }^{6}$ Alcohol intake database developed by the Department of Psychiatry, Kasturba Hospital was used for evaluating drinking related variables. MINI-PLUS was administered in order to rule out any comorbid psychiatric diagnosis. $^{7}$

Analysis of data was carried out using SPSS (Statistical package for social sciences) version 13.0. Descriptive statistics were used. Group comparison for categorical variables was done by using chi square test and Fisher's exact test of probability, wherever appropriate.

\section{RESULTS}

A total of $125(\mathrm{~N})$ consenting individuals were divided into two groups on the basis of the treatment centre they belonged to (Tertiary care centre, Kasturba hospital, TH-75 (N1) and Secondary care centre, Udupi District hospital, SH-50 (N2)). After administering the instruments as mentioned above, analysis of data was done using appropriate methods as explained above.

Mean age of patients at the time of evaluation was found to be 44.73 ( \pm 10.60$)$ among the patients evaluated at $\mathrm{TH}$, while among SH patients, it was 39.58 ( \pm 11.39$)$. Only one patient was female, evaluated at Tertiary hospital; $87.2 \%$ of the total patients were Hindu, and $59.2 \%$ were from LSES. The two groups differed significantly in marital status, place of residence, type of family, occupational status and level of education as illustrated in the table. (Table 1)

There was no statistically significant difference among the two groups in relation to the total duration of drinking, maximum period of abstinence, frequency of abstinence and relapse. However, significant differences were seen in the age of onset of drinking and duration of last drink. (Table 2)

Individuals who take 1-2 drinks per day but not more than nine drinks in a week were regarded as low risk drinkers; while those drinking more than 21 drinks per week were considered problem drinkers. Binge drinkers were the individuals who take more than five drinks per occasion. In $\mathrm{TH}$, maximum (68\%) of patients were low risk drinkers in comparison to the patients at $\mathrm{SH}(50 \%)$, which was found to be statistically significant $(p<0.05)$. (Table 3 )

Almost one-third of the total sample had never undergone deaddiction treatment in the past. No statistical significance 
Table 1. Distribution of Socio-demographic variables in patients with Alcohol Dependence Syndrome ( $\mathrm{N}=125)$.

\begin{tabular}{|c|c|c|c|c|c|}
\hline S.N. & Variables & $\begin{array}{l}\text { Tertiary } \\
\text { level } \\
\text { Hospital } \\
\mathrm{N}_{1}=75 \\
(\%)\end{array}$ & $\begin{array}{l}\text { Second- } \\
\text { ary level } \\
\text { Hospital } \\
\mathrm{N}_{2}=50 \\
(\%)\end{array}$ & $\begin{array}{l}\text { Total } \\
\mathrm{N}=125 \\
(\%)\end{array}$ & $\begin{array}{l}\text { Statistics } \\
X^{2} \\
\text { df } \\
p \text {-value }\end{array}$ \\
\hline \multirow[t]{2}{*}{1} & Mean Age & 44.73 & 39.58 & & \\
\hline & $( \pm S D)$ & $( \pm 10.60)$ & $( \pm 11.39)$ & & \\
\hline \multirow[t]{2}{*}{2} & Sex & & & & \\
\hline & $\begin{array}{l}\text { Male } \\
\text { Female }\end{array}$ & $\begin{array}{l}74(98.7) \\
1(1.3)\end{array}$ & $\begin{array}{l}50(100) \\
0(0)\end{array}$ & $\begin{array}{l}124 \\
(99.2) \\
1(0.8)\end{array}$ & $\begin{array}{l}0.672 \\
1 \\
0.412\end{array}$ \\
\hline \multirow[t]{2}{*}{3} & Marital status & & & & \\
\hline & $\begin{array}{l}\text { Married } \\
\text { Single, } \\
\text { Separated or } \\
\text { Divorced }\end{array}$ & $\begin{array}{l}70(93.3) \\
5(6.7)\end{array}$ & $\begin{array}{l}38(76) \\
12(24)\end{array}$ & $\begin{array}{l}108 \\
(86.4) \\
17(13.6)\end{array}$ & $\begin{array}{l}8.488 \\
2 \\
0.008 *\end{array}$ \\
\hline \multirow[t]{2}{*}{4} & Religion & & & & \\
\hline & $\begin{array}{l}\text { Hindu } \\
\text { Others }\end{array}$ & $\begin{array}{l}65(86.7) \\
10(13.4)\end{array}$ & $\begin{array}{l}44(88) \\
6(12)\end{array}$ & $\begin{array}{l}109 \\
(87.2) \\
16(12.8)\end{array}$ & $\begin{array}{l}0.395 \\
2 \\
0.821\end{array}$ \\
\hline \multirow[t]{2}{*}{5} & Residence & & & & \\
\hline & $\begin{array}{l}\text { Urban } \\
\text { Rural }\end{array}$ & $\begin{array}{l}54(72) \\
21(28)\end{array}$ & $\begin{array}{l}31(62) \\
19(38)\end{array}$ & $\begin{array}{l}85(68) \\
40(32)\end{array}$ & $\begin{array}{l}6.098 \\
2 \\
0.047^{*}\end{array}$ \\
\hline \multirow[t]{2}{*}{6} & Family type & & & & \\
\hline & $\begin{array}{l}\text { Nuclear } \\
\text { Others }\end{array}$ & $\begin{array}{l}45(60) \\
30(40)\end{array}$ & $\begin{array}{l}18(36) \\
32(64)\end{array}$ & $\begin{array}{l}63(50.4) \\
62(49.6)\end{array}$ & $\begin{array}{l}9.988 \\
2 \\
0.004 * *\end{array}$ \\
\hline \multirow[t]{2}{*}{7} & \multicolumn{5}{|c|}{ Socioeconomic status } \\
\hline & $\begin{array}{l}\text { LSES } \\
\text { MSES and } \\
\text { above }\end{array}$ & $\begin{array}{l}40(53.3) \\
35(46.6)\end{array}$ & $\begin{array}{l}34(68) \\
16(32)\end{array}$ & $\begin{array}{l}74(59.2) \\
51(40.8)\end{array}$ & $\begin{array}{l}3.090 \\
2 \\
0.160\end{array}$ \\
\hline \multirow[t]{2}{*}{8} & \multicolumn{5}{|c|}{ Occupational status } \\
\hline & $\begin{array}{l}\text { Farmer } \\
\text { Laborer } \\
\text { Professional } \\
\text { Homemaker / } \\
\text { Other }\end{array}$ & $\begin{array}{l}23(30.7) \\
22(29.3) \\
23(30.7) \\
7(9.2)\end{array}$ & $\begin{array}{l}10(20) \\
29(58) \\
3(6) \\
8(16)\end{array}$ & $\begin{array}{l}33(26.4) \\
51(40.8) \\
26(20.8) \\
15(12)\end{array}$ & $\begin{array}{l}24.560 \\
8 \\
0.000 * * *\end{array}$ \\
\hline \multirow[t]{2}{*}{9} & \multicolumn{5}{|c|}{ Educational status } \\
\hline & $\begin{array}{l}\text { No formal } \\
\text { education } \\
\text { Below SSLC } \\
\text { SSLC and } \\
\text { above }\end{array}$ & $\begin{array}{l}2(2.6) \\
33(44) \\
40(53.3)\end{array}$ & $\begin{array}{l}10(20) \\
28(56) \\
12(24)\end{array}$ & $\begin{array}{l}12(9.6) \\
61(48.8) \\
52(41.6)\end{array}$ & $\begin{array}{l}23.602 \\
7 \\
0.001 * *\end{array}$ \\
\hline
\end{tabular}

was found between the two groups of patients in relation to the past history of deaddiction. However, in relation to the past history of hospitalization for the purpose of deaddiction or other medical reasons, difference between the two groups was statistically significant.

Problems in employment like loss of job, demotions, disciplinary actions, suspensions; damage of property, treatment costs, debts etc for purchase of alcohol in the last five year period were inquired for assessing financial problems. Physical fights, drunken driving, arrests, court cases etc were asked to document legal problems.
Table 2. Distribution of drinking related variables in patients with Alcohol Dependence Syndrome ( $N=125)$.

$\begin{array}{|lllll|}\begin{array}{l}\text { S. } \\ \text { N. }\end{array} \begin{array}{l}\text { Drinking } \\ \text { related vari- } \\ \text { ables }\end{array} & \begin{array}{l}\text { Tertiary } \\ \text { level hos- } \\ \text { pital } \\ \text { N1=75 } \\ \text { (\%) }\end{array} & \begin{array}{l}\text { Second- } \\ \text { ary level } \\ \text { hospital } \\ \text { N2 }=50(\%)\end{array} & \begin{array}{l}\text { Total } \\ \mathbf{N}=125 \\ (\%)\end{array} & \begin{array}{l}\text { Statistics } \\ \mathbf{X}^{2} \\ \text { df }\end{array} \\ \text { p-value }\end{array}$

Table 3. Distribution of different patterns of drinking in patients with Alcohol Dependence Syndrome ( $\mathrm{N}=125$.

\begin{tabular}{|c|c|c|c|c|c|}
\hline S. & $\begin{array}{l}\text { Drinking } \\
\text { patterns }\end{array}$ & $\begin{array}{l}\text { Tertiary } \\
\text { level hos- } \\
\text { pital } \\
\text { N1=75 (\%) }\end{array}$ & $\begin{array}{l}\text { Second- } \\
\text { ary level } \\
\text { hospital } \\
\text { N2 =50 (\%) }\end{array}$ & $\begin{array}{l}\text { Total } \\
\mathrm{N}=125(\%)\end{array}$ & $\begin{array}{l}\text { Statis- } \\
\text { tics } \\
\text { X2 } \\
\text { df } \\
\text { p-value }\end{array}$ \\
\hline 1 & $\begin{array}{l}\text { Low risk } \\
\text { drinkers }\end{array}$ & $51(68)$ & $25(50)$ & $76(60.8)$ & \multirow{3}{*}{$\begin{array}{l}7.827 \\
2 \\
0.020 *\end{array}$} \\
\hline 2 & $\begin{array}{l}\text { Problem } \\
\text { drinkers }\end{array}$ & $17(22.7)$ & $11(22)$ & $28(22.4)$ & \\
\hline 3 & $\begin{array}{l}\text { Binge drink- } \\
\text { ers }\end{array}$ & 7 (9.3) & $14(28)$ & $21(16.8)$ & \\
\hline
\end{tabular}

Problems in family, interpersonal relationships with spouse, children and other relatives were the areas assessed as the social problems due to alcohol. There was no statistically significant difference in legal and social problems among the two groups, though the financial problems differed significantly. (Table 4)

Adding the five sections of the SAD-Q (physical withdrawal, affective withdrawal relief, typical daily consumption and features in the morning after two days of heavy drinking following four weeks of abstinence), total score was calculated, score above 35 was considered to reflect severe alcohol dependence. Statistically significant difference was found among them. (Table 5)

Assessment of alcohol related medical morbidities among the patients in both the hospitals revealed $81.6 \%$ of total sample having different medical morbidities, the most common of these being that of $\mathrm{Gl}$, maximum of which was Alcoholic Liver Disease. All such illustrated statistically significant differences in the two treatment centers. (Table 6) 
Table 4. Distribution of different alcohol related problems in patients with Alcohol Dependence Syndrome ( $N=125)$.

\begin{tabular}{|c|c|c|c|c|c|}
\hline S.N. & $\begin{array}{l}\text { Alcohol } \\
\text { related } \\
\text { problems }\end{array}$ & 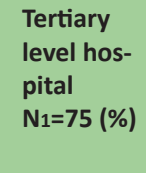 & $\begin{array}{l}\text { Second- } \\
\text { ary level } \\
\text { hospital } \\
\mathrm{N}_{2}=50 \\
(\%)\end{array}$ & $\begin{array}{l}\text { Total } \\
\mathrm{N}=125 \text { (\%) }\end{array}$ & $\begin{array}{l}\text { Statistics } \\
\mathrm{X}^{2} \\
\text { df } \\
\mathrm{p} \text {-value }\end{array}$ \\
\hline \multirow[t]{2}{*}{1} & \multicolumn{5}{|c|}{ Financial problems } \\
\hline & $\begin{array}{l}\text { No } \\
\text { Yes }\end{array}$ & $\begin{array}{l}27(36) \\
48(64)\end{array}$ & $\begin{array}{l}8(16) \\
42(84)\end{array}$ & $\begin{array}{l}35(28) \\
90(72)\end{array}$ & $\begin{array}{l}5.952 \\
1 \\
0.015^{*}\end{array}$ \\
\hline \multirow[t]{2}{*}{2} & \multicolumn{5}{|c|}{ Legal problems } \\
\hline & $\begin{array}{l}\text { No } \\
\text { Yes }\end{array}$ & $\begin{array}{l}70(93.3) \\
5(6.7)\end{array}$ & $\begin{array}{l}44(88) \\
6(12)\end{array}$ & $\begin{array}{l}114(91.2) \\
11(8.8)\end{array}$ & $\begin{array}{l}1.063 \\
1 \\
0.302\end{array}$ \\
\hline \multirow[t]{2}{*}{3} & \multicolumn{5}{|c|}{ Social problems } \\
\hline & $\begin{array}{l}\text { No } \\
\text { Yes }\end{array}$ & $\begin{array}{l}36(48) \\
39(42)\end{array}$ & $\begin{array}{l}23(46) \\
27(54)\end{array}$ & $\begin{array}{l}59(47.2) \\
66(52.8)\end{array}$ & $\begin{array}{l}0.048 \\
1 \\
0.826\end{array}$ \\
\hline $\begin{array}{l}{ }^{*} \mathrm{p}<0.0 \\
\text { Table } \\
\text { score) }\end{array}$ & $\begin{array}{l}5,{ }^{* *} \mathrm{p}<0.01 \\
\text { 5. Distribu } \\
\text { in patient }\end{array}$ & $\begin{array}{l}* * p<0.001 \\
\text { on of Severi } \\
\text { with Alcoho }\end{array}$ & $\begin{array}{l}\text { ty of Alcor } \\
\text { I Depende }\end{array}$ & $\begin{array}{l}\text { nol Depende } \\
\text { nce Syndrom }\end{array}$ & $\begin{array}{l}\text { nce (SAD-C } \\
\text { ne }(N=125) \text {. }\end{array}$ \\
\hline S.N. & $\begin{array}{l}\text { SAD-Q To- } \\
\text { tal score }\end{array}$ & $\begin{array}{l}\text { Tertiary } \\
\text { level hos- } \\
\text { pital } \\
\text { N1=75 (\%) }\end{array}$ & $\begin{array}{l}\text { Second- } \\
\text { ary level } \\
\text { hospital } \\
\mathrm{N}_{2}=50 \\
(\%)\end{array}$ & $\begin{array}{l}\text { Total } \\
\mathrm{N}=125 \\
(\%)\end{array}$ & $\begin{array}{l}\text { Statistics } \\
\mathrm{X}^{2} \\
\mathrm{df} \\
\mathrm{p} \text {-value }\end{array}$ \\
\hline 1 & $<35$ & $28(37.3)$ & $8(16)$ & $36(28.8)$ & 6.658 \\
\hline 2 & $>35$ & $47(62.7)$ & $42(84)$ & $89(71.2)$ & $\begin{array}{l}1 \\
0.015^{*}\end{array}$ \\
\hline $\begin{array}{l}{ }^{*} \mathrm{p}<0.0 \\
\text { Table } \\
\text { patier } \\
\text { 6.1: P }\end{array}$ & $\begin{array}{l}5,{ }^{* *} p<0.01 \\
\text { 6. Distribu } \\
\text { ts with Alc } \\
\text { resence an }\end{array}$ & $\begin{array}{l}{ }^{*} \mathrm{p}<0.001 \\
\text { on of alcol } \\
\text { hol Depend } \\
\text { Absence of }\end{array}$ & $\begin{array}{l}\text { ol relatec } \\
\text { ence Sync } \\
\text { medical n }\end{array}$ & $\begin{array}{l}\text { medical mo } \\
\text { ome ( } N=125 \\
\text { rbidity: }\end{array}$ & $\begin{array}{l}\text { orbiditie } \\
\text { 5). }\end{array}$ \\
\hline S.N. & $\begin{array}{l}\text { Medical } \\
\text { morbidi- } \\
\text { ties }\end{array}$ & 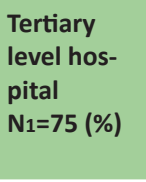 & $\begin{array}{l}\text { Second- } \\
\text { ary level } \\
\text { hospital } \\
\mathrm{N}_{2}=50 \\
(\%)\end{array}$ & $\begin{array}{l}\text { Total } \\
\mathrm{N}=125 \\
(\%)\end{array}$ & $\begin{array}{l}\text { Statistics } \\
x^{2} \\
\text { df } \\
p \text {-value }\end{array}$ \\
\hline 1 & Yes & $67(89.3)$ & $35(70)$ & $102(81.6)$ & 7.468 \\
\hline 2 & No & $8(10.7)$ & $15(30)$ & $23(18.4)$ & $\begin{array}{l}1 \\
0.006^{*}\end{array}$ \\
\hline
\end{tabular}

6.2: Varieties of medical morbidity:

\begin{tabular}{|c|c|c|c|c|c|c|}
\hline S.N. & $\begin{array}{l}\text { Medical } \\
\text { morbid- } \\
\text { ity }\end{array}$ & $\begin{array}{l}\text { Tertiary } \\
\text { level hos- } \\
\text { pital } \\
\mathrm{N}_{1=75} \\
(\%)\end{array}$ & $\begin{array}{l}\text { Second- } \\
\text { ary } \\
\text { level } \\
\text { hospital } \\
\mathrm{N}_{2}=50 \\
(\%)\end{array}$ & $\begin{array}{l}\text { Total } \\
\mathrm{N}=125 \\
(\%)\end{array}$ & $\begin{array}{l}\text { Statistics } \\
x^{2} \\
\text { df } \\
p \text {-value }\end{array}$ & $\begin{array}{l}\text { Statis- } \\
\text { tics } \\
\mathrm{X}^{2} \\
\text { df } \\
\text { p-value }\end{array}$ \\
\hline 1 & Nil & $8(10.7)$ & $15(30)$ & $15(30)$ & $23(18.4)$ & \multirow{4}{*}{$\begin{array}{l}17.183 \\
6 \\
0.003 * *\end{array}$} \\
\hline 2 & $\begin{array}{l}\text { Gastro- } \\
\text { intesti- } \\
\text { nal (GI) }\end{array}$ & $37(49.3)$ & $28(56)$ & $28(56)$ & $65(52)$ & \\
\hline 3 & Others & $9(12)$ & $4(8)$ & $4(8)$ & $13(10.4)$ & \\
\hline 4 & $\begin{array}{l}\text { Com- } \\
\text { bined }\end{array}$ & $21(28)$ & $3(6)$ & $3(6)$ & $24(19.2)$ & \\
\hline
\end{tabular}

6. 3: Gastrointestinal (GI) morbidity:

\begin{tabular}{|c|c|c|c|c|c|}
\hline S.N. & $\begin{array}{l}\text { Alcohol } \\
\text { related GI } \\
\text { morbidi- } \\
\text { ties }\end{array}$ & $\begin{array}{l}\text { Tertiary } \\
\text { level hos- } \\
\text { pital } \\
\text { N1}_{1}=75(\%)\end{array}$ & $\begin{array}{l}\text { Second- } \\
\text { ary level } \\
\text { hospital } \\
\text { N2 =50 (\%) }\end{array}$ & $\begin{array}{l}\text { Total } \\
\mathrm{N}=125 \\
(\%)\end{array}$ & $\begin{array}{l}\text { Statistics } \\
\mathrm{x}^{2} \\
\text { df } \\
\text { p-value }\end{array}$ \\
\hline 1 & $\begin{array}{l}\text { Alco- } \\
\text { holic Liver } \\
\text { Disease } \\
\text { (ALD) }\end{array}$ & $28(37.3)$ & $26(52)$ & $54(43.2)$ & \multirow{7}{*}{$\begin{array}{l}18.791 \\
6 \\
0.005^{* *}\end{array}$} \\
\hline 2 & Cirrhosis & $8(10.7)$ & $3(6)$ & $11(8.8)$ & \\
\hline 3 & $\begin{array}{l}\text { ALD with } \\
\text { Cirrhosis }\end{array}$ & $8(10.7)$ & $0(0)$ & $8(6.4)$ & \\
\hline 4 & $\begin{array}{l}\text { Pancre- } \\
\text { atitis }\end{array}$ & $3(4)$ & $0(0)$ & $3(2.4)$ & \\
\hline 5 & $\begin{array}{l}\text { Portal } \\
\text { hyperten- } \\
\text { sion }\end{array}$ & $4(5.3)$ & $1(2)$ & $5(4)$ & \\
\hline 6 & Others & $16(21.3)$ & $5(10)$ & $21(16.8)$ & \\
\hline 7 & Nil & $8(10.7)$ & $15(30)$ & 23 (18.4) & \\
\hline
\end{tabular}

\section{DISCUSSION}

With the aim to study and compare the Alcohol drinking patterns, Alcohol use disorders and Alcohol related medical morbidities among the patients with Alcohol Dependence Syndrome presented to psychiatry services at Secondary care treatment center and Tertiary care treatment center, we attempted this study enrolling total number of 125 patients (75 in Tertiary care center and 50 in Secondary care center).

The study showed significant differences among the two groups in relation to some of the socio-demographic variables studied. Mean age of the patients at TH was 44.73( \pm 10.60$)$, while at $\mathrm{SH}$, it was 39.58 ( \pm 11.39 ) showing that majority of patients with ADS fall in middle age group, which is in keeping with the findings from the Bangalore Study. ${ }^{1}$ Only one female patient was seen at $\mathrm{TH}$, all others were males, hence gender differences among the sample population cannot be interpreted in this study. Some of the earlier studies have also showed ADS more among the males and middle- aged individuals. ${ }^{8-10}$ More patients from urban residence, nuclear family background, Middle socio-economic status and above were seen among the $\mathrm{TH}$ samples while maximum patients in $\mathrm{SH}$ were laborers and uneducated or below SSLC. Similar findings were seen in the Bangalore study with ADS found more among the married, illiterate, unskilled workers who were below the poverty line residing at rural/ slum areas. ${ }^{1}$ The majority of uneducated and lower income patients found in SH may be because Udupi centre geographically caters to low income population and it is the centre where free drug and food is available.

Majority of patients at SH had started drinking below 18 years and maximum frequency of the patients at that hospital presented within two weeks of the last drink. Interpretation of the findings in relation to the duration of last drink may not be realistic as we have excluded the 
patients in alcohol withdrawal related delirium and most of these delirious patients present to the hospital within 72 hours of the last drink. Median duration of drinking was found more than 15 years in both the hospital samples which are in keeping with the findings from the Bangalore study. ${ }^{1}$ Majority of patients in both the hospital samples had irregular periods of abstinence and frequent relapses as has been seen in the literature related to ADS.,3,8-10

TH patients had maximum frequency of low risk drinkers while binge drinkers were seen more among the $\mathrm{SH}$ patients; problem drinkers being almost equal in both the patient groups. Interpretation of these results in relation to the findings from earlier studies may not show comparable statistics as the definition of drinking patterns has not been the same in all those studies as explained above. One study done more than a decade back among the western population found more population with heavy drinking. ${ }^{11}$ However, a recent Indian study showed maximum frequency of problem drinking. ${ }^{12}$ In the Bangalore study, it was found that more than half of the sample population were regular drinkers and maximum population of rural sample were having "Binge drinking pattern" centered around pay-day or special occasions like festivals and marriages with hard drinks like "arracks" and whisky being used by the maximum population. ${ }^{1}$ This finding is more or less replicated in our study which also showed that maximum patients in $\mathrm{SH}$ (which is representative of patients from LSES, laborers, illiterate and rural population) had binge pattern of drinking. We could not look into the distribution of the different types of beverages used in our study population as our sample population was small confined mostly to a particular locality and they were found to be using different types of beverages (local "arracks", beer, whisky, brandy etc) at different periods of time.

There was significant differences in relation to the past history of hospitalization (either for medical cause or for de-addiction) among the two patient groups with maximum patients in $\mathrm{SH}$ group being never hospitalized in the past. It shows that $\mathrm{SH}$ has group of patients who may not be aware of the need for treatment as seen in the study among SEAR countries or they may be either noncompliant to the treatment or attend hospital only with serious complications. ${ }^{2}$ It might be correlated with their irregular abstinence patterns and frequent relapses.

Both the groups showed maximum patients reporting of financial problems related to alcohol, but more than $80 \%$ of $\mathrm{SH}$ patients had financial problems and it was statistically significant. This can be explained with the fact that maximum patients in SH were from LSES background, laborers/ daily wage earners and they might have been spending their daily earnings in alcohol as was found in the Bangalore study. ${ }^{1}$

We intended to differentiate between the two groups in relation to the severity of alcohol dependence on the basis of scores obtained in SAD-Q as was done in a hospital based study. ${ }^{13}$ We calculated the total SAD-Q score and those scoring below 35 were considered having mild to moderate dependence, while those scoring above 35 were considered severe dependence. ${ }^{6,14}$ There was significant difference among the two groups with above $80 \%$ of patients from SH having severe dependence.

Almost $90 \%$ of patients in TH had medical morbidities of some kind. Almost half of these morbidities were related to gastrointestinal system; alcoholic liver disease with or without cirrhosis, portal hypertension and pancreatitis being the predominant illness related to alcohol. Both the study groups had higher frequency of diseases related to gastrointestinal system; keeping with the results of the earlier studies looking into alcohol related mortality and morbidity.,11,15-17 In our study, more morbidity detected in the TH population may be due to the frequent use of radiological (Ultrasonography, CT/MRI) and investigation facilities as well as the presence of a well co-ordinated consultation-liaison services.

No statistically significant relationship was found between the drinking patterns and alcohol related medical morbidities as gastrointestinal morbidities were more in patients with all the three patterns of drinking as in a study by Wetterling et al. ${ }^{11}$ However, a study looking at the five-year outcome in Alcohol Dependence showed maximum frequency of heavy drinkers with gastrointestinal complications. ${ }^{18}$ More than $70 \%$ of binge drinkers scored above 35 in SAD-Q, but no statistical significance was seen. Some recent studies have shown the relationship between drinking patterns and cardiovascular morbidity; but our study could not replicate the findings as frequency of cardiovascular diseases in our study sample was very small. ${ }^{19-23}$ Our sample might have been largely based upon the referrals for de-addiction from Gastroenterology clinic or those patients referred there for liver complications leading gastrointestinal morbidities to form the major bulk in our morbidity statistics.

In summary, there were significant differences in some socio-demographic parameters among the patients from the two different treatment centers, with secondary level hospital having more illiterate, laborers and below the poverty line population. More binge drinkers were seen in $\mathrm{SH}$ while more low risk drinkers in $\mathrm{TH}$. Maximum frequency of gastro-intestinal morbidities was seen in both the hospital population, irrespective of the patterns of drinking.

Our Study had certain limitations too. Due to small sample size and hospital based nature of the study, representative community sample could not be obtained and the problem (both medical and psychosocial) might not have been explored adequately. 


\section{CONCLUSION}

Alcohol use disorders and alcohol related medical morbidities show some variations in their presentations in different treatment centers. Most of the patients presenting to the district level government hospital were illiterate, laborers, below the poverty line and binge drinkers. Maximum frequency of gastro-intestinal morbidities was seen in both the hospital population, irrespective of the patterns of drinking.

\section{REFERENCES}

1. Gururaj G, Girish N, Benegal V. Burden and socio-economic impact of Alcohol- The Bangalore Study, Alcohol control series-1. WHO Regional office for South East Asia;2006.

2. World Health Organization. WHO Global Status Report on Alcohol, Country profile, South-East Asian Region, Nepal. 2004 : 79-94.

3. Rehm J, Sulkowska U, Man'czuk M, Boffetta P, Powles J, Popova S, et al. Alcohol accounts for a high proportion of premature mortality in Central and Eastern Europe. Int. J. Epidemiol 2007; 36 (2):458-67.

4. Schuckit MA. Alcohol and Alcoholism. In: Kasper DL, Braunwald E., Fauci AS, Hauser SL, Longo DL, Jameson JL. Harrison's Principles of Internal Medicine (vol. II): Alcoholism and Drug Dependence. 16th edition. The Mc Graw -Hill Companies, Inc;2005.p.2562-70.

5. American Psychiatric Association. Diagnostic and Statistical manual of Mental Disorders. 4th edition, Revised (DSM-IV TR). Washington: American Psychiatric Press DC; 1994.

6. Stockwell T, Murphy D, Hodgson R. The severity of alcohol dependence questionnaire: Its use, reliability and validity. British Journal of Addiction 1983; 78(2): 45-156.

7. Sheehan DV, Lecrubier $Y$, Sheehan KH, Amorim P, Janavs J, Weiller E, et al. The Mini-International Neuropsychiatric Interview (M.I.N.I.): the development and validation of a structured diagnostic psychiatric interview for DSM-IV and ICD-10. J Clin Psychiatry 1998; 59 (Suppl 20):22-33.

8. Shu-I Wu, Shen-Ing Liu, Chun-Kai Fang, Chien-Chi Hsu, Yi-Wen Sun. Prevalence and detection of alcohol use disorders among general hospital inpatients in eastern Taiwan. General Hospital Psychiatry 2006; 28: 48- 54

9. Hao W, Su Z, Liu B, Zhang K, Yang H, Chen S, et al. Drinking and drinking patterns and health status in the general population of five areas of china. Alcohol \& Alcoholism 2004; 39(1): 43-52.

10. Smothers BA, Yahr HT, Ruh CE. Detection of Alcohol Use Disorders in General Hospital Admissions in the United States. Arch Intern Med 2004; 164:749-56.

11. Wetterling $T$, Veltrup $C$, Driessen $M$, John U. Drinking pattern and alcohol related medical disorders. Alcohol and Alcoholism 1999; 34 (3): 330-6.

\section{ACKNOWLEDGEMENTS}

We would like to thank all the staffs of Kasturba Hospital and Udupi District Hospital for their guidance, suggestion and support in this study; and all the patients who participated in this research for their kind consent and patience during the phase of lengthy interrogation and examination.

12. Sampath SK, Chand PK, Murthy P. Problem Drinking Among Male Inpatients in a Rural General Hospital (Letter to Editor). Indian Journal of Community Medicine 2007; 32 (1).

13. Smith S, White J, Nelson C, Davies M, Lavers J, Sheron N. Severe alcohol-induced liver disease and the alcohol dependence syndrome. Alcohol and Alcoholism 2006; 41 (3): 274-7.

14. Stockwell T, Sitharan T, McGrath D. The measurement of alcohol dependence and impaired control in community samples. Addiction 1994; 89: 167-74.

15. Stokkeland K, Hilm G, Spak F, Franck J, Hultcrantz R. Different Drinking Patterns for Women and Men With Alcohol Dependence With and Without Alcoholic Cirrhosis. Alcohol and Alcoholism 2008; 43(1):3945.

16. Rehm J, Gmel G, Christopher T, Trevisan M. Alcohol-related morbidity and mortality. Alcohol Research and Health 2003; 27: 39-53.

17. Taylor B, Rehm J, Gmel G. Moderate Alcohol Consumption and the Gastrointestinal Tract. Dig Dis 2005; 23:170-6.

18. Gual A, Lligona A, Colom J. Five Year outcome in Alcohol Dependence: A naturalistic study of 850 patients in Catalonia. Alcohol and Alcoholism 1999; 34 (2):183-92.

19. Murray RP, Connett JE, Tyas SL, Bond R, Ekuma O, Silversides CK, et al. Alcohol Volume, Drinking Pattern, and Cardiovascular Disease Morbidity and Mortality: Is There a U-shaped Function? American Journal of Epidemiology 2002; 155 (3): 242-8.

20. Tolstrup J, Jensen MK, Tjonneland A, Overvad K, Mukamal KJ, Grønbæk M. Prospective study of alcohol drinking patterns and coronary heart disease in women and men. BMJ 2006; 332:1244-8.

21. Stranges S, Wu T, Dorn JM, Freudenheim JL, Muti P. Relationship of Alcohol Drinking Pattern to Risk of Hypertension: A Population-Based Study. Hypertension 2004; 44:813-9.

22. Chick J. Alcohol, Health, and the Heart: Implications for Clinicians. Alcohol \& Alcoholism 1998; 33 (6): 576-91.

23. Lopez EP, Rice C, Weddle O, Rahill GJ. The Relationship among Cardiovascular Risk Factors, Diet Patterns, Alcohol Consumption, and Ethnicity among Women Aged 50 Years and Older. J Am Diet Assoc 2008; 108: 248-56. 